\title{
Implementing AMETTA (Active, Joyful, and Unstressed) in Increasing Learning Activity and Outcomes
}

\author{
Yenni Hasnah1, Pirman Ginting 2, Selamat Husni Hasibuan 3 \\ DOI: $10.35445 /$ alishlah.v13i1.300
}

\section{Info Artikel}

Keywords:

AMETTA learning

model

Learning outcomes

Learning activity

Kata kunci:

Model pembelajaran

AMETTA

Hasil belajar

Aktivitas belajar

\section{Abstract}

This research aims to analyze the learning model's practice and its effect on increasing student activity and learning outcomes in listening subjects. This study employed quasi-experimental research with a non-equivalent control group design. The data were gained using observation and tests. It is analyzed by reflection and statistical test of SPPS. The results show that the application of the AMETTA learning model effectively develops student learning activities and outcomes. The result of hypothesis testing with sig. (2-tailed) was $0.033(<$ 0.05) It indicates that Ho is rejected. Thus, there is a significant difference between the average student learning outcomes in the experimental and control classes. In other words, the application of AMETTA learning model has a significant effect on students' learning outcomes.

\begin{abstract}
Abstrak
Penelitian ini bertujuan untuk menganalisis praktik model pembelajaran dan pengaruhnya terhadap peningkatan aktivitas dan hasil belajar mahasiswa pada mata kuliah menyimak. Studi ini dilaksanakan dengan menggunakan eksperimen semu (quasy experiment) dengan desain nonequivalent control group. Data diperoleh melalui observasi dan tes dan dianalisis dengan menerapkan proses refleksi dan uji statistik SPPS. Hasil penelitian menunjukkan bahwa penerapan model pembelajaran AMETTA efektif dalam meningkatka aktivitas dan hasil belajar mahasiswa. Hasil uji hipotesis dengan sig. (2-tailed) adalah o,033 $(<0$,05) mengindikasikan bahwa Ho ditolak. Dengan demikian, terdapat perbedaan yang signifikan antara rata-rata hasil belajar mahasiswa antara kelas eksperimen dan kontrol. Dengan kata lain, penerapan model pembelajaran AMETTA dalam pembelajaran berpengaruh baik terhadap hasil belajar mahasiswa.
\end{abstract}

\section{PENDAHULUAN}

\footnotetext{
${ }^{1}$ Universitas Muhammadiyah Sumatera Utara, Medan, Indonesia

Email: yennihasnah@umsu.ac.id

${ }_{2}$ Universitas Muhammadiyah Sumatera Utara, Medan, Indonesia Email: pirmanginting@umsu.ac.id

3 Universitas Muhammadiyah Sumatera Utara, Medan, Indonesia Email: selamathusni@umsu.ac.id
} 
Salah satu komponen penting yang menentukan kualitas pendidikan adalah proses pembelajaran yang secara formal melibatkan dua komponen utama lainnya yaitu pendidik dan peserta didik. Proses tersebut menggambarkan bagaimana rangkaian kegiatan yang dilakukan pendidik dan peserta didiknya dalam pembelajaran yang dapat diistilahkan sebagai model pembelajaran. Hanafiah dan Suhana (2009) menjelaskan bahwa model pembelajaran berkaitan erat dengan gaya belajar peserta didik dan gaya mengajar guru yang sering dikenal dengan style of learning and teaching. Pemilihan model pembelajaran yang tepat tentunya sangat berpengaruh terhadap pencapaian tujuan belajar yang hendak dicapai. Seperti yang disampaikan oleh Suprijono (2009) bahwa model pembelajaran adalah kerangka konseptual tentang prosedur sistematis dalam mengorganisasikan pengalaman belajar untuk mencapai tujuan belajar, baik pembelajar maupun pengajar. Kemudian, model pembelajaran juga dapat difungsikan sebagai salah satu upaya untuk membantu perbaikan dalam mengajar (Iru dan Arihi, 2012). Berdasarkan pernyataan tersebut terlihat jelas bahwa model pembelajaran dapat digunakan sebagai salah satu upaya untuk mewujudkan tujuan pembelajaran.

Pendidik (dosen/guru) yang merupakan salah satu pemeran dalam pembelajaran mempunyai peranan vital dalam menciptakan pembelajaran yang berkualitas melalui pelaksanaan model-model pembelajaran yang aktif, menyenangkan dan tanpa tekanan, sehingga dapat memberikan dampak positif terhadap peningkatan kualitas peserta didik, baik secara kognitif, psikomotorik, maupun afektif. Model pembelajaran tersebut akan terealisasi dalam bentuk interaksi yang interaktif, harmonis, dan menyenangkan, baik antara pendidik dan peserta didik maupun antar sesama pelajar itu sendiri. Interaksi seperti ini tentunya berdampak sangat signifikan pada peningkatan kualitas pembelajaran pelajar yang terindikasi melalui aktivitas dan capaian prestasi belajar yang maksimal.

Namun pada kenyataannya, tidak sedikit para pendidik yang masih nyaman dengan model pembelajaran klasik yang beranggapan bahwa pendidik menjadi pusat dalam pembelajaran dan seolah-olah menjadi satu-satunya referensi. Hal ini tentunya menciptakan ketidakseimbangan dalam proses interaksi pembelajaran, yang mana pendidik lebih mendominasi melalui ceramah ataupun penjelasan yang disampaikan sehingga sebagian besar peserta didik secara langsung atau tidak hanya berperan sebagai pendengar atau penonton. Dalam kondisi ini, tingkat keaktifan peserta didik dalam pembelajaran sangat minim. Sebagai konsekuensinya, peserta didik memiliki kemandirian belajar yang cukup rendah, lebih banyak bergantung pada penjelasan dosen yang sering ditayangkan melalui tayangan power point atau bahkan hanya melalui penjelasan lisan semata. Kondisi pembelajaran seperti ini tidak jarang juga menimbulkan kebosanan dalam diri pembelajar apalagi jika dalam menjelaskan si pendidik kadang bersikap kurang menyenangkan. Alhasil, pembelajaran akan membuat pembelajar menjadi kurang aktif, bosan, tidak nyaman, dan bahkan ada yang tertekan jika si pendidik memberikan intimidasi bagi yang tidak memperhatikan penjelasannya dengan serius.

Kondisi pembelajaran di atas mendorong tim peneliti untuk menawarkan sebuah model pembelajaran dimana peserta didik akan menjadi subjek utama dalam melakukan proses pembelajaran sehingga mereka berperan lebih aktif, tidak bosan, dan bahkan mereka akan merasa senang dalam belajar. Model pembelajaran yang dimaksud adalah model pembelajaran yang Aktif, Menyenangkan, dan Tanpa Tekanan yang disingkat dengan AMETTA. Model ini merupakan sebuah model pembelajaran yang dirancang pada penelitian tim peneliti sebelumnya yang menyimpulkan bahwa desain model pembelajaran AMETTA layak digunakan sebagai model pembelajaran dalam meningkatkan kualitas pembelajaran (Hasnah, Ginting \& Dewi, 2020). Hal ini terlihat darifeedback yang diberikan oleh para validator dengan rata-rata persentase validasi ahli sebesar $76.04 \%$ dan validasi audience (hasil angket respon mahasiswa) sejumlah 79,79\% pada uji coba skala kecil dan $88,08 \%$ pada skala besar. 
Model pembelajaran AMETTA merupakan model pembelajaran yang dapat menghasilkan kegiatan pembelajaran yang aktif, menyenangkan dan tanpa beban (Hasnah, Ginting \& Dewi, 2020). Definisi tersebut memberikan makna bahwa model pembelajaran ini bercirikan aktif, menyenangkan, dan tanpa tekanan sehingga dapat menyebabkan perubahan yang lebih baik dalam diri peserta didik, baik secara kognitif, psikomotorik, maupun afektif.

Pembelajaran aktif (active learning) merupakan kegiatan pembelajaran yang menekankan pengalaman belajar pada diri peserta didik. Dengan kata lain, pembelajaran aktif menjadikan peserta didik sebagai pusat pembelajaran sehingga mereka memiliki kemandirian dalam melakukan eksperimen-eksperimen pengembangan diri, baik dari segi keterampilan maupun ilmu pengetahuan. Siahaan (2014) menyatakan bahwa pembelajaran aktif dimaksudkan untuk mengoptimalkan semua potensi yang dimiliki oleh peserta didik sehingga semua peserta dapat mencapai hasil belajar yang memuaskan sesuai dengan karakteristik pribadi yang mereka miliki.

Pembelajaran menyenangkan (joyful learning) merupakan proses pembelajaran yang tidak membosankan, rileks, dan kondusif, serta terdapatnya aktivitas pembelajaran yang bervariasi sehingga dapat menciptakan hubungan/interaksi yang efektif, baik antara pendidik dan peserta didik maupun antar sesama peserta didik itu sendiri. Seperti yang dijelaskan oleh Mulyasa (2007) bahwa pembelajaran menyenangkan (joyful instruction) merupakan suatu proses pembelajaran yang didalamnya terdapat suatu kohesi yang kuat antara pendidik dan peserta didik, tanpa ada perasaan terpaksa atau tertekan. Selanjutnya, Rusman (2011) menyatakan bahwa dalam pembelajaran menyenangkan perlu diciptakan suasana yang demokratis dan tidak ada beban, baik guru maupun siswa dalam melakukan proses pembelajaran. Dalam hal ini, guru dapat memposisikan diri sebagai mitra belajar siswa, bahkan dalam hal tertentu tidak menutup kemungkinan guru belajar dari siswanya.

Pelaksanaan pembelajaran menyenangkan sangat penting untuk meningkatkan kualitas pembelajaran, sehingga hal tersebut juga dicantumkan dalam Peraturan Pemerintah No.19 pasal 19 ayat 1 berbunyi "proses pembelajaran pada satuan pendidikan diselenggarakan secara interaktif, inspiratif, menyenangkan, menantang, memotivasi peserta didik untuk berpartisipasi aktif, memberikan ruang gerak yang cukup bagi prakarsa, kreativitas, dan kemandirian sesuai dengan bakat, minat dan perkembangan fisik, serta psikologi anak didik". Oleh karena itu, seorang pendidik harus mampu memiliki kompetensi untuk menghasilkan pembelajaran yang menyenangkan sehingga dapat menunjang tercapainya tujuan pembelajaran yang diharapkan.

Dalam pembelajaran tanpa tekanan (unstressed learning) menggarisbawahi bahwa pada dasarnya merupakan proses interaksi antara peserta didik dan lingkungan untuk membentuk perubahan tingkah laku kearah yang lebih baik. Dalam konteks interaksi antara peserta didik dengan pendidik, seorang pendidik yang baik harus mampu menciptakan komunikasi yang baik sehingga peserta didik mereka merasa nyaman dan rileks. Hasilnya, para peserta didik dapat mengikuti proses pembelajaran dengan sepenuh hati tanpa ada perasaan tertekan. Sejalan dengan hal tersebut, Sanusi (2013) menyebutkan bahwa tugas utama pendidikan adalah untuk menjalin komunikasi dan relasi personal antara pribadi-pribadi dan pribadi dengan kelompok di dalam komunitas sekolah. Relasi ini berkembang dengan pesat dan menghasilkan buah-buah pendidikan jika dilandasi oleh cinta kasih diantara mereka. Pribadi-pribadi hanya berkembang secara optimal dan relatif tanpa hambatan jika berada dalam suasana yang penuh cinta (unconditional love), hati yang penuh pengertian (understanding heart), serta relasi pribadi yang efektif (personal relationship). Dari pandangan tersebut dapat dinyatakan bahwa seorang pendidik dalam mendidik peserta didiknya harus menjadikan mereka suatu individu yang utuh yang tidak hanya membutuhkan peningkatan ilmu pengetahuan tetapi mampu menbentuk mereka menajdi pribadi-pribadi yang berperilaku lebih baik.

Mengacu pada pendapat Sanusi (2013) di atas, maka seorang pedidik tidak seharusnya memandang peserta didik sebagai subjek yang dipersalahkan dengan memberikan mereka labellabel negatif, seperti ungkapan meyalahkan, menghardik, mengejek dan bahkan memberi hukuman 
(fisik dan nilai) atas kemampuan mereka yang masih rendah atau perilaku yang dipandang belum baik. Pelabelan dan pemberian hukuman tersebut cenderung menghasilkan suasana pembelajaran yang tidak nyaman.

Berdasarkan uraian di atas, maka sangat perlu untuk melaksanakan pembelajaran aktif, menyenangkan, dan tanpa tekanan sehingga tujuan pembelajaran dapat tercapai dengan baik, yakni berkembangnya potensi peserta didik baik secara kognitif, psikomotorik, maupun afektif. Melalui penelitian ini diterapkan sebuah model pembelajaran yang dimaksud, yakni model pembelajaran AMETTA untuk mengetahui keefektifan model tersebut dalam meningkatkan aktivitas dan hasil belajar peserta didik. Penelitian ini sangat penting dilakukan karena merupakan penelitian lanjutan dari penelitian sebelumnya yang menghasilkan desain model pembelajaran AMETTA. Jadi, desain tersebut sangat perlu diuji keefektifannnya melalui penerapan model tersebut dalam kegiatan pembelajaran sebelum dilakukan pengembangan selanjutnya. Hasil penelitian ini nantinya dapat digunakan sebagai alternatif model pembelajaran yang efektif untuk menciptakan suasana pembelajaran yang aktif, menyenangkan dan tanpa tekanan dalam rangka meningkatkan kualitas pendidikan yang terwujud melalui capaian hasil belajar yang optimal, baik secara kognitif, psikomotorik, maupun afektif.

\section{METODE PENELITIAN}

Penelitian ini adalah penelitian kuantitatif dengan menggunakan rancangan penelitian eksperimen semu (quasy experiment) dengan desain nonequivalent control group. Penelitian dilakukan selama semester genap pada tahun akademik 2019/2020. Populasi dalam penelitian ini adalah seluruh mahasiswa semester enam pada Program Studi Pendidikan Bahasa Inggris Fakultas Keguruan dan Ilmu Pendidikan Universitas Muhammadiyah Sumatera Utara yang berjumlah lima kelas. Pengambilan sampel dalam penelitian ini menggunakan teknik cluster random sampling atau acak kelas. Setelah melakukan acak kelas maka ditentukan dua kelas sebagai sampel. Dari dua kelas tersebut diundi kembali secara acak untuk menentukan kelas kontrol dan kelas eksperimen. Dari hasil random diperoleh kelas VI B pagi sebagai kelas eksperimen dan kelas VI C pagi sebagai kelas kontrol. Kelas eksperimen diberikan perlakuan menggunakan model pembelajaran AMETTA.

Metode pengumpulan data dilakukan melalui observasi aktivitas dan tes hasil belajar mahasiswa. Lembar observasi digunakan untuk mengamati aktivitas belajar mahasiswa selama proses pembelajaran. Kemudian, tes diberikan untuk mengukur kemampuan menyimak (listening skill) mahasiswa yang meliputi tes awal (pretest) dan tes akhir (posttest). Tes awal digunakan untuk mengetahui kemampuan awal menyimak mahasiswa. Jika hasil tes menunjukkan hasil yang relatif sama antara kelompok eksperimen dan kelompok kontrol maka penelitian ditindaklanjuti. Tes akhir dilakukan untuk mengukur hasil belajar mahasiswa setelah mereka mengikuti pembelajaran.

Data penelitian terdiri atas aktivitas dan hasil belajar mahasiswa. Untuk aktivitas belajar mahasiswa dianalisis berdasarkan kategori nilai seperti yang disajikan pada tabel di bawah ini (Sari, 2017).

Tabel 1. Skala Nilai dan Kategori Aktivitas Belajar Mahasiswa

\begin{tabular}{cc}
\hline Nilai & Kategori \\
\hline $81-100$ & Baik Sekali \\
$61-80$ & Baik \\
$41-60$ & Cukup \\
$21-40$ & Kurang \\
$0-20$ & Sangat Kurang \\
\hline
\end{tabular}

Sedangkan untuk hasil belajar dianalisis dengan menggunakan uji-t yang diolah dengan bantuan Statistical Product and Service Solution (SPSS) meliputi analisis gain normalisasi, uji normalitas, uji homogenitas dan uji hipotesis. Normalized Gain dilakukan untuk mengetahui efektifitas peningkatan hasil belajar mahasiswa yang diperoleh dari selisih nilai pre-test dan post- 
test. Untuk mengetahui apakah data pada setiap variabel berkontribusi normal, maka dilakukan uji normalitas. Oleh karena itu, pengujian normalitas dilaksanakan sebelum pelaksanaan uji hipotesis. Uji homogenitas data dilakukan untuk mengetahui apakah kedua kelas tersebut memiliki varian yang sama atau penguasaan materi yang homogen. Pada tahap akhir analisis dilakukan uji hipotesis.

\section{HASIL DAN PEMBAHASAN}

Penelitian ini bertujuan untuk menginvestigasi peningkatan aktivitas belajar dan hasil belajar mahasiswa melalui penerapan model pembelajaran AMETTA (Aktif, Menyenangkan, dan Tanpa Tekanan). Penelitian ini merupakan jenis penelitan quasi-eksperimen yang dilaksanakan pada dua kelas yang berbeda yakni kelas eksperimen dan kelas kontrol, dimana kelas eksperimen mendapatkan perlakuan melaui penerapan model pembelajaran AMETTA dan kelas kontrol tanpa diberi perlakuan. Hasil belajar mahasiswa yang diuji berupa kemampuan mendengar (listening skill). Sebelum kegiatan pembelajaran dilaksanakan, kedua kelompok kelas diberikan tes (pre-test) untuk mengukur tingkat keterampilan awal mendengarkan mahasiswa. Setelah proses pembelajaran selesai, dilakukan tes akhir untuk mengetahui peningkatan dan perbedaan kemampuan mendengar mahasiswa (listening) antara kelompok kontrol dan eksperimen. Selain itu, selama proses pembelajaran juga dilakukan pengamatan terhadap aktivitas belajar mahasiswa untuk mengetahui dampak penerapan model pembelajaran AMETTA terhadap aktivitas mahasiswa selama proses pembelajaran berlangsung.

\section{Aktivitas Belajar Mahasiswa melalui Penerapan Model Pembelajaran AMETTA}

Dalam kegiatan pembelajaran, keterlibatan aktif peserta didik menjadi suatu faktor penting untuk mencapai tujuan pembelajaran secara optimal dan sangat berpengaruh terhadap hasil belajar mereka (Novianty, 2017). Aktivitas belajar tidak hanya meliputi keterlibatan mahasiswa dalam proses belajar, tetapi juga mencakup sikap, dan perhatian (Jumarniati \& Anas, 2019). Pada penelitan ini, evaluasi terhadap keaktifan belajar mahasiswa meliputi aktivitas visual, lisan, mendengar, menulis, mental dan emosional (Sardiman, 2016). Berikut adalah hasil pengamatan dan evaluasi aktivitas belajar mahasiswa selama proses pembelajaran menggunakan model pembelajaran AMETTA.

\section{Aktivitas Visual (Visual Activities)}

Prilaku mahasiswa yang diamati pada aspek ini yakni kegiatan mahasiswa dalam memperhatikan dan menyimak penjelasan dosen dan pertanyaan mahasiswa, serta mengamati materi pembelajaran melalui video. Kedua indikator tersebut dinilai melalui skor antara satu sampai empat yang juga berlaku sama untuk semua indikator pada aktivitas belajar selanjutnya dan nilai akhirnya dikonversikan dengan beberapa kategori, yakni baik sekali, baik, cukup dan kurang.

Tabel 2. Persentase Aktivitas Visual

\begin{tabular}{cllr}
\hline Aspek & Nilai & Kategori & Persentase \\
\hline \multirow{2}{*}{ Aktivitas } & $81-100$ & Baik sekali & $24,39 \%$ \\
Visual & $41-80$ & Baik & $39,02 \%$ \\
& $20-40$ & Cukup & $31,7 \%$ \\
& Kurang & $4,87 \%$ \\
\hline
\end{tabular}

Data pada tabel di atas menunjukkan tingkat persentase jumlah mahasiswa atas keterlibatan mereka dalam proses pembelajaran dari segi aktivitas pandang (visual). Pada kategori baik sekali, terdapat $24,39 \%$ jumlah mahasiswa yang berpartisipasi secara visual pada proses pembelajaran dan 39,02\% kategori baik. Dari hasil pengamatan terlihat mahasiswa secara antusias memperhatikan dosen pada saat menjelaskan pembelajaran. Selain itu, mahasiswa juga secara sungguh-sungguh menyimak penjelasan tentang instruksi latihan soal yang disampaikan oleh dosen dan pertanyaan atau respon yang diberikan oleh mahasiswa. Kesungguhan mahasiswa juga diperlihatkan pada saat mengamati video contoh latihan yang diputar oleh dosen. 
Sementara itu, sebanyak 31,7\% dari total jumlah mahasiswa berada pada kategori cukup. Aktivitas visual pada tataran ini yang diperlihatkan melalui atensi dan pengamatan dinilai cukup baik. Ketekunan mereka dalam menyimak penjelasan materi juga dapat dikategorikan cukup meskipun terkadang mereka terlihat kurang acuh terhadap kelas dan berbicara dengan temannya. Selanjutnya, sejumlah 4,87\% mahasiswa memperoleh nilai kurang. Pada kategori ini, mahasiswa kurang aktif mengikuti kegiatan pembelajaran. Mereka hanya sekali-sekali memperhatikan dosen saat menyajikan materi. Mahasiswa lebih sering diam dan berbicara dengan mahasiswa disebelahnya. Salah satu alasan rendahnya parstisipasi aktif mahasiswa adalah disebabkan oleh ketidakpahaman mereka terhadap materi yang disampaikan.

\section{Aktivitas Lisan (Oral Activities)}

Indikator yang diukur pada aktivitas lisan yaitu mengajukan pertanyaan kepada dosen, menjawab dan menanggapi pertanyaan baik dari dosen maupun dari mahasiswa lainnya, dan keterampilan dalam menyampaikan pendapat atau saran. Ketiga indikator tersebut diberikan nilai dengan skor antara satu hingga empat.

\section{Tabel 3. Persentase Aktivitas Lisan}

\begin{tabular}{cllr}
\hline Aspek & Nilai & Kategori & Persentase \\
\hline \multirow{2}{*}{ Aktivitas } & $81-100$ & Baik sekali & $9,75 \%$ \\
Lisan & $41-80$ & Baik & $56,09 \%$ \\
& $20-40$ & Cukup & $31,7 \%$ \\
& Kurang & $2,43 \%$ \\
\hline
\end{tabular}

Persentase jumlah mahasiswa dengan kategori nilai baik merupakan kategori yang paling dominan dibandingkan dengan aspek lainnya, yakni sebanyak 56,09\%, dan pada tingkat baik sekali, terdapat sebanyak 9,75\%. Mahasiswa sangat aktif mengikuti proses pembelajaran. Kesempatan bertanya yang diberikan oleh dosen dimanfaatkan oleh mahasiswa untuk menyampaikan pertanyaan dan tanggapan. Mahasiswa juga aktif dalam memberikan pendapat dan saran terhadap materi yang didiskusikan. Sejumlah $31,7 \%$ berada pada kategori cukup. Keaktifan mahasiswa direfleksikan melalui pemberian pertanyaan dan tanggapan kepada dosen dan kepada pertanyaan yang disampaikan oleh mahasiswa lain. Namun, pada saat yang sama, mahasiswa juga sering tidak acuh atau tidak fokus pada pembelajaran dan banyak bercerita antar sesama mereka. Di sisi lain, sebagian mahasiswa juga memiliki partisipasi yang rendah selama proses pembelajaran, yakni sebesar 2,43\% dengan nilai kategori kurang.

\section{Aktivitas Mendengar (Listening Activities)}

Aktivitas mendengar juga merupakan salah satu aspek penting yang untuk mengukur aktivitas belajar mahasiswa. Indikator yang diukur pada bagian ini adalah partisipasi mahasiswa dalam mendengarkan penjelasan dosen dan pernyataan atau pendapat mahasiswa. Penilaian indikator ini berada antara skor 1-4. Tabel berikut merupakan hasil penilaian terhadap aktivitas mendengar (listening activities) mahasiswa.

Tabel 4. Persentase Aktivitas Mendengar

\begin{tabular}{cllr}
\hline Aspek & Nilai & Kategori & Persentase \\
\hline \multirow{2}{*}{ Aktivitas } & $81-100$ & Baik sekali & $9,75 \%$ \\
Visual & $41-60$ & Baik & $58,53 \%$ \\
& $20-40$ & Cukup & $29,26 \%$ \\
\hline
\end{tabular}

Kategori nilai sangat baik dan baik pada aktivitas mendengar mahasiswa pada kegiatan pembelajaran adalah 9,75\% dan 58,53\% secara berturut-turut. Hasil ini diperoleh dari pengamatan 
terhadap kesungguhan mahasiswa dalam mengikuti dan menyimak penjelasan materi. Tanggapan yang disampaikan terhadap argumen atau jawaban dari mahasiswa yang lain membuktikan bahwa mahasiswa tersebut menyimak pembelajaran dengan baik. Sementara itu, nilai cukup mencapai 29,26\%. Kesungguhan mahasiswa dalam menyimak penjelasan dari dosen dan diskusi dari teman dikategorikan sedang atau cukup karena aktivitas menyimak mahasiswa sering kali terganggu dengan aktivitas lainya, seperti berbicara antar sesama. Gangguan ini seringkali mengalihkan fokus mahasiswa dari mendengarkan pembelajaran. Lebih lanjut, 2,43\% dari total keseluruhan mahasiswa mendapatkan nilai aktivitas mendengar dengan kategori kurang. Penilaian ini didasarkan pada hasil pengamatan yang menunjukkan bahwa mahasiswa cenderung kurang peduli terhadap pembelajaran. Mereka sering mengabaikan penjelasan dengan lebih banyak bercerita dengan teman sebelah. Mahasiswa perempuan, khususnya, juga sering disibukkan dengan aktivitas bercermin.

\section{Aktivitas Menulis (Writing Activities)}

Pada penelitian ini, aktivitas menulis juga menjadi bagian penting dalam mengukur aktivitas belajar mahasiswa. Indikator yang digunakan untuk mengukur aktivitas menulis mahasiswa adalah kegiatan note-taking, yakni kegiatan mencatat informasi penting tentang materi pembelajaran, baik pada saat penjelasan maupun saat melakukan latihan dalam menjawab soal. Indikator tersebut dinilai dengan rentangan skor satu sampai empat. Berdasarkan hasil evaluasi, diperoleh hasil sebagai berikut.

Tabel 5. Persentase Aktivitas Menulis

\begin{tabular}{cllc}
\hline Aspek & Nilai & Kategori & Persentase \\
\hline \multirow{2}{*}{ Aktivitas } & $81-100$ & Baik sekali & $9,75 \%$ \\
Menulis & $61-80$ & Baik & $63,41 \%$ \\
& $41-60$ & Cukup & $26,82 \%$ \\
\hline
\end{tabular}

Seperti halnya pada aktivitas lain, peringkat nilai aktivitas menulis mahasiswa yang paling tinggi juga berada pada kategori baik (63,41\%), sedangkan kategori baik sekali sejumlah 9,75\%. Antusiasme mahasiswa mengikuti pembelajaran sangat tinggi. Mereka terlihat sangat aktif menulis dan membuat catatan terutama pada saat mendengarkan materi latihan menyimak. Di samping itu, jumlah mahasiswa yang memiliki klasifikasi keaktifan menulis cukup, yakni 26,82\%. Kemampuan mahasiswa dalam memahami dan menangkap informasi penting tentang materi yang disampaikan mempengaruhi kemampuan mereka dalam menuliskan catatan materi. Misalnya, pada saat mengerjakan latihan soal listening mahasiswa terlihat mengalami kesulitan untuk mencatat, bahkan terlihat pasrah dan melewatkan beberapa informasi. Persoalan ini menjadi salah satu penyebab mahasiswa kurang aktif untuk menulis.

\section{Aktivitas Mental (Mental Activities)}

Penilaian aktivitas mental diukur melalui beberapa indikator, diantaranya kegiatan dalam menganalisis dan menanggapai pertanyaan dan jawaban, mengingat materi yang telah diulas sebelumnya, dan mengambil keputusan dalam menentukan jawaban dari pertanyaan yang diskusikan. Ketiga jenis kegiatan dalam aktivitas mental ini dijadikan sebagai indikator penilaian yang mana setiap indikatornya dinilai dalam rentangan skor 1-4. Total akhir skor diberikan konversi dengan merujuk pada kategori seperti yang disajikan dalam tabel di bawah ini.

Tabel 6. Persentase Aktivitas Mental

\begin{tabular}{cllr}
\hline Aspek & Nilai & Kategori & Persentase \\
\hline \multirow{3}{*}{ Aktivitas } & $81-100$ & Baik sekali & $9,75 \%$ \\
Mental & $41-60$ & Baik & $58,53 \%$ \\
& $20-40$ & Cukup & $29,26 \%$ \\
& Kurang & $2,43 \%$ \\
\hline
\end{tabular}


Paparan data di atas merupakan distribusi tingkat aktivitas mental mahasiswa pada proses pembelajaran, yang terbagi ke dalam empat kategori. Besaran persentase mahasiswa yang memiliki kategori nilai baik sekali adalah 9,75\%. Sementara itu, jumlah mahasiswa dengan nilai aktivitas mental kategori baik berada pada angka 58,53\%. Kedua kategori nilai ditelaah dari keterlibatan mahasiswa yang aktif selama kegiatan pembelajaran. Selama proses pembelajaran, mahasiswa sangat bersemangat menganalisi soal yang didiskusikan. Lebih lanjut, mereka sangat aktif dalam memberikan pertanyaan bila terdapat materi atau soal yang tidak dipahami, dan tidak merasa malu untuk memberikan tanggapan terhadap pertanyaan yang muncul. Mereka juga aktif dalam menyampaikan jawaban atas pertanyaan yang diberikan dan mengaitkannya dengan materi yang telah dipelajari sebelumnya.

Meskipun masih terdapat banyak kesalahan dalam menentukan jawaban secara tepat, mahasiswa tetap berusaha untuk menggali informasi terkait materi diskusi yang sedang dipelajari. Karakteristik mahasiswa seperti ini dikelompokkan kepada nilai aktivitas mental cukup dengan jumlah mahasiswa mencapai 29,26\%. Bahkan, terdapat mahasiswa yang tingkat partisipasinya sangat rendah. Mereka cenderung diam, walaupun mereka terlihat menulis sedikit catatan pada saat pembelajaran. Persentase jumlah mahasiswa pada ketegori ini (kurang) adalah 2,43\%.

\section{Aktivitas Emosional (Emotional Activities)}

Tolok ukur aktivitas emosional mahasiswa selama pembelajaran diidentifikasi dari semangat dan rasa gembira dalam mengikuti kegiatan pembelajaran dan keberanian (kepercayaan diri) dalam mengutarakan pertanyaan atau tanggapan. Kedua indikator tersebut juga dinilai melalui skor yang serupa dengan aktivitas-aktivitas belajar sebelumnya, yakni dalam rentangan skor satu hingga empat yang kemudian nilai akhirnya dikonversikan sehingga mengacu pada beberapa kategori yaitu baik sekali, baik, cukup dan kurang.

Tabel 7. Persentase Aktivitas Emosional

\begin{tabular}{cllc}
\hline Aspek & Nilai & Kategori & Persentase \\
\hline \multirow{3}{*}{ Aktivitas } & $81-100$ & Baik sekali & $19,51 \%$ \\
Emosional & $41-60$ & Baik & $56,09 \%$ \\
& $20-40$ & Cukup & $21,95 \%$ \\
& Kurang & $2,43 \%$ \\
\hline
\end{tabular}

Model pembelajaran AMETTA yang diterapkan dalam pembelajaran sangat berpengaruh terhadap aktivitas belajar mahasiswa. Pembelajaran yang aktif, menyenangkan dan tanpa tekanan sangat efektif dalam membangun rasa semangat dan gembira mahasiswa. Bentuk rasa semangat dan gembira mahasiswa tersebut terealisasi dari antusiasme mereka dalam berdiskusi dan mengerjakan latihan soal. Tambahan lagi, tingkat kepercayaan mahasiswa dalam mengajukan pertanyaan dan memberi tanggapan juga dapat dikategorikan baik sampai sangat baik. Pada saat menyampaikan pertanyaan, mereka tidak terlihat gugup, begitu juga pada saat mengutarakan pandangan mereka terhadap pertanyaan yang ada. Jumlah mahasiswa yang tergolong kepada kriteria di atas dengan tingkat nilai baik sekali sebesar 19,51\%, sementara pada level baik berjumlah 56,09\%.

Namun, masih terdapat mahasiswa yang kurang berpartisipasi secara aktif pada kegiatan pembelajaran. Mereka terlihat masih kurang percaya diri untuk menyampaikan pertanyaan. Begitu juga, saat mereka memberikan respon terhadap pertanyaan yang disampaikan oleh dosen. Mereka masih merasa gugup. Oleh karena itu, dosen perlu untuk menyemangati dan memotivasi mereka untuk membangun kepercayaan diri mereka. Karakteristik aktivitas mental seperti ini dikelompokkan kepada nilai cukup dengan jumlah mahasiswa mencapai 21,95\%. Bahkan, terdapat mahasiswa yang tingkat partisipasinya sangat rendah. Mereka cenderung diam, walaupun mereka terlihat membuat sedikit catatan pada saat proses pembelajaran. Jumlah mahasiswa pada ketegori ini (kurang) mencapai 2,43\%. 
Berdasarkan uraian aktivitias belajar mahasiswa dengan menggunakan model pembelajaran AMETTA (Aktif, Menyenangkan, dan Tanpa Tekanan) di atas, maka secara kesuluruhan dinilai baik. Hasil nilai aktivitas belajar mahasiswa tersebut diukur dari enam indikator; aktivitas visual, mendengar, lisan, menulis, mental dan emosional. Dari hasil yang diperoleh bahwa jumlah mahasiswa yang memiliki kriteria nilai baik pada setiap indikator tergolong signifikan: aktivitas visual (39,02\%), aktivitas lisan (56,09), aktivitas mendengar (58,53\%), aktivitas menulis $(63,41 \%)$, aktivitas mental (58,53\%), dan aktivitas emosional (56,09\%). Sementara itu, persentase mahasiswa dengan tingkat nilai aktivitas mahasiswa sangat baik mencapai $24,39 \%$ pada indikator aktivitas visual, 19,51\% pada aktivitas emosional, dan 9,75\% pada tiga indikator aktivitas belajar lainnya. Kemudian, Nilai aktivitas mahasiswa dengan kategori cukup pada keenam indikator tersebut berkisar antara 21,95\% - 31,7\%. Sebaliknya, hanya terdapat 2,43\% sampai 4,87\% mahasiswa yang memperoleh nilai cukup.

\section{Hasil Belajar Mahasiswa}

Pengujian hasil belajar mahasiswa diawali dengan pemberian pretest kepada kedua sampel untuk mengetahui tingkat kemampuan awal mahasiswa. setelah memperoleh hasil pre-test, penelitian dilanjutkan dengan memberikan perlakuan kepada kelompok eksperimen dengan menerapkan model pembelajaran AMETTA (Aktif, Menyenangkan, dan Tanpa Tekanan), sedangkan kelas kontrol tidak mendapatkan perlakuan. Hal ini sesuai dengan model desain penelitian yang diterapkan, yakni quasi-eksperimen dimana grup kontrol tidak memperoleh perlakuan. Selanjutnya, dilakukan post-test untuk mengukur keberhasilkan atau pengaruh model pembelajaran AMETTA dalam meningkatkan hasil belajar mahasiswa. Pada pre-test, diperoleh nilai rata-rata mahasiswa kelas eksperimen sebesar 71,83, dan kelas kontrol sebesar 71,32, sedangkan nilai rata-rata post-test kedua grup adalah 80 (kelas eksperimen) dan 76,57 (kelas kontrol).

Untuk menguji hipotesis perlu dilakukan pengujian prasyarat analisis terlebih dahulu terhadap data hasil penelitian, yakni uji normalitas dan homogenitas untuk mengetahui apakah data yang diperoleh berdistribusi normal dan homogenitas.

Pengujian normalitas menggunakan kolmogorove Smirnov. Uji normalitas dilaksanakan untuk mengukur apakah data berasal dari populasi berdistribusi normal atau tidak. Data dapat dinyatakan berasal dari populasi berdistribusi normal jika memenuhi kriteria asymp sig $\leq$ 0.05, maka sampel berdistrubisi tidak normal. Sebaliknya, jika asymp sig > 0.05, maka sampel berdistrubsi normal. Data uji normalitas dapat dilihat pada tabel berikut.

Tabel 8. Hasil Uji Normalitas Kelas Experimen

\begin{tabular}{|c|c|c|}
\hline & & d Residual \\
\hline $\mathrm{N}$ & & 41 \\
\hline Normal & Mean & .0000000 \\
\hline Parameters $^{\mathrm{a}, \mathrm{b}}$ & Std. Deviation & 3.84475374 \\
\hline & Absolute & .182 \\
\hline $\begin{array}{l}\text { Most Extreme } \\
\text { Differences }\end{array}$ & Positive & .182 \\
\hline & Negative & -.135 \\
\hline Kolmogorov-S & ov Z & 1.164 \\
\hline Asymp. Sig. (2 & & 133 \\
\hline
\end{tabular}

Tabel di atas menunjukkan bahwa nilai signifikansi Asymp.Sig (2 tailed) pada kelas eksperimen sebesar 0,133 lebih dari nilai tabel Uji Kolmogorov-Smirnov pada $\alpha=0.05$. Sesuai dengan dasar pengambilan keputusan dalam uji normalitas komogorov-smirnov di atas, maka data dapat dinyatakan berdistrubsi normal.

Pengujian normalitas juga dilakukan pada kelas kontrol untuk mengetahui apakah data pada kelompok kontrol juga berasal dari populasi berdistribusi normal. 
Tabel 9. Nilai Uji Normalitas Kelas Kontrol

\begin{tabular}{llr}
\hline & & Unstandardized Residual \\
\hline $\mathrm{N}$ & & 38 \\
Normal & Mean & .0000000 \\
Parameters $^{\mathrm{a}, \mathrm{b}}$ & Std. Deviation & .46037762 \\
& Absolute & .171 \\
Most Extreme & Positive & .171 \\
Differences & Negative & -.137 \\
& Kolmogorov-Smirnov Z & 1.052 \\
Asymp. Sig. (2-tailed) & .219 \\
\hline
\end{tabular}

Berdasarkan tabel output SPSS di atas, diketahui bahwa nilai signifikansi Asymp.Sig (2 tailed) mencapai o, 219, lebih besar dari pada $\alpha=0$, 05. Perbedaan nilai tersebut mengindikasikan bahwa sebaran data berasal dari populasi yang berdistribusi normal.

Setelah diperolah hasil uji normalitas, dilakukan uji homogentias untuk mengetahui apakah suatu varians data dari dua atau lebih kelompok bersifat sama (homogen) atau berbeda (heterogen). Analisis uji homogenitas dijadikan sebagai suatu syarat dalam pengujian perbedaan rata-rata. Varian data dinyatakan homogen jika nilai signifikansi (sig) Based on Mean > 0,05. Sebaliknya, jika nilai signifanksi (sig) Based on Mean < 0,05, maka varian data adalah tidak homogen. Untuk mengetahui nilai homogenitas dilakukan pengujian terhadap data (post-test) dari kedua kelompok eksperimen dan kelas kontrol dengan menggunakan SPSS (Levene Test). Dari proses analisis data, diperoleh hasil uji homogenitas seperti yang tertera pada tabel output Test of Homogenity of Variance di bawah ini.

Tabel 1o. Tabel Uji Homogenitas Varian Pretest dan Posttest

\begin{tabular}{cccccc}
\hline & & $\begin{array}{c}\text { Levene } \\
\text { Statistic }\end{array}$ & $\mathrm{df} 1$ & $\mathrm{df} 2$ & Sig. \\
\hline Tes Awal & Based on Mean & 2.355 & 1 & 58 & .130 \\
Tes Akhir & Based on Mean & 2.464 & 1 & 58 & .122 \\
\hline
\end{tabular}

Dari tabel hasil di atas diketahui nilai Signifikansi Based on Mean untuk variabel tes awal pada kelompok perlakuan dan kontrol adalah sebesar 0,130 (> 0,05) dengan Leven Statistic $=2.355$. Hasil ini membuktikan bahwa kedua kelompok sampel berasal dari populasi yang memiliki varian sama. Pengujian homogenitas juga diterapkan pada hasil belajar mahasiswa (tes akhir). Data pada tabel output memperlihatkan bahwa nilai Signifikansi Based on Mean pada kelas eksperimen dan kontrol untuk variabel tes akhir mencapai 0,122, lebih besar dari 0,05, dengan Leven Statistic 2,464. Maka dapat disimpulkan bahwa data hasil belajar mempunyai varian yang sama. Karena kedua data berdistribusi normal dan bersifat homogen, maka dilanjutkan dengan pengujian hipotesis melalui uji-t (Independent Sample T-Test).

Pengujian hipotesis berpedoman pada hasil uji-t. Uji-t adalah suatu analisis untuk membandingkan dua sampel yang tidak saling berhubungan. Uji-t dilakukan karena diperoleh hasil bahwa data kedua sampel berdistrubsi normal dan kedua sample memiliki varian yang sama. Berdasarkan tabel output uji independent sample test diketahui nilai Sig. Levene's Test for Equality of Variances adalah sebesar 0,122 (> 0,05). Oleh karena itu, dapat disimpulkan bahwa varian antara grup eksperimen dan kontrol adalah homogen atau sama. Dengan demikian, interpretasi hasil independent sample test di atas berpedoman pada nilai equal variances assumed. Ditinjau dari equal variances assumed terdapat nilai sig. (2-tailed) mencapai 0,033<0,05, maka dapat dinyatakan Ho ditolak dan Ha diterima. Dengan kata lain, terdapat perbedaan yang signifikan antara rata-rata hasil belajar siswa pada kelas eksperimen dan kontrol. 
Hasil penelitian di atas menunjukkan bahwa penerapan model pembelajaran AMETTA, sebuah model pembelajaran aktif, menyenangkan, dan tanpa tekanan, berpengaruh baik terhadap aktivitas dan hasil belajar mahasiswa. Temuan ini mengindikasikan bahwa sebuah model pembelajaran aktif akan menunjang keaktifan pelajar yang akhirnya bermuara pada perbaikan hasil belajar mereka seperti yang disimpulkan oleh Kariadi \& Suprapto (2018) bahwa proses pembelajaran aktif melalui strategi pengajuan pertanyaan akan mampu mendorong keterlibatan siswa dalam setiap langkah pembelajaran yang pada akhirnya juga akan berpengaruh terhadap hasil pembelajaran yang lebih baik. Hal ini juga sejalan dengan hasil penelitian yang disampaikan oleh Dzulfikri dan Joko (2013) bahwa kelas yang menggunakan metode pembelajaran aktif dengan strategi pembelajaran reconnecting lebih baik dari pada siswa diberi pembelajaran langsung. Kedua temuan tim peneliti di atas menegaskan bahwa penerapan pembelajaran aktif berkontribusi dalam menciptakan pembelajaran yang bermutu yang diindikasikan oleh adanya partisipasi aktif siswa dalam pembelajaran, sehingga berdampak pada peningkatan prestasi mereka. Sebagai tambahan bahwa pembelajaran aktif dapat dilaksanakan dengan variasi strategi yang berbeda seperti yang dilakukan oleh kedua tim peneliti di atas, yakni pembelajaran aktif melalui strategi pengajuan pertanyaan dan pembelajaran aktif dengan strategi pembelajaran reconnecting, dan strategi dalam penlitian ini, yaitu model pembelajaran AMETTA berbantu senam otak.

Terkait hasil penelitian bahwa aktivitas belajar mahasiswa dikategorikan baik meliputi berbagai kegiatan yang ditunjukkan oleh mahasiswa dalam pembelajaran. Hal tersebut senada dengan apa yang disampaikan oleh Kunandar (2013) bahwa tolok ukur peningkatan aktivitas belajar siswa dapat dilihat dari meningkatnya jumlah peserta didik yang terlibat aktif belajar, meningkatanya jumlah mahasiswa/siswa yang bertanya dan menjawab, dan meningkatnya jumlah mahasiswa/siswa terlibat (yang saling berinteraksi) membahas materi pelajaran. Dengan kata lain, keaktifan belajar peserta didik tidak hanya ditinjau melalui kegiatan tunggal (satu aktivitas saja) melainkan adanya variasi aktivitas pembelajaran yang dilakukan.

\section{SIMPULAN}

Penerapan model pembelajaran AMETTA (Aktif, Menyenangkan, dan Tanpa Tekanan) dapat meningkatkan aktivitas belajar mahasiswa yang meliputi aktivitas visual, mendengar, lisan, menulis, mental dan emosional. Hal tersebut terlihat dari masing-masing aktivitas memiliki persentase tertinggi berada pada kategori baik. Peningkatan aktivitas belajar tersebut tentunya berdampak terhadap hasil belajar mahasiswa yang juga membaik. Berdasarkan hasil uji hipotesis dengan nilai sig. (2-tailed) adalah o,033 (<0,05), maka dapat dinyatakan Ho ditolak dan Ha diterima. Artinya, terdapat perbedaan yang signifikan antara rata-rata hasil belajar mahasiswa antara kelas eksperimen dan kontrol. Dengan kata lain, penerapan model pembelajaran AMETTA dalam pembelajaran berpengaruh baik terhadap hasil belajar mahasiswa.

Dalam upaya meningkatkan keaktifan pembelajar, model pembelajaran AMETTA (Aktif, Menyenangkan, dan Tanpa Tekanan) dapat digunakan sebagai salah satu alternatif model pembelajaran. Dalam prakteknya, para pendidik dapat menerapkan model ini dengan variasi metode pembelajaran yang sesuai dengan tujuan pembelajaran yang hendak dicapai. Selanjutnya, bagi para peneliti diharapkan dapat melakukan kajian lebih lanjut lanjut terkait hasil penelitian ini sehingga memperoleh temuan-temuan yang dapat dikembangkan lebih luas lagi.

\section{DAFTAR PUSTAKA}

Dzulfikri, M. \& Joko. (2013). Pengaruh metode pembelajaran aktif dengan strategi pembelajaran reconnecting terhadap hasil belajar siswa pada mata pelajaran menggunakan hasil pengukuran kelas xi titl semester i di smkn 7 surabaya. Jurnal Pendidikan Teknik Elektro, 2 (2), 515-522.

Hanafiah, N., \& Suhana, C. (2009). Konsep Strategi Pembelajaran. Bandung: Refika Aditama.

Hasnah, Y., Ginting, P., \& Dewi, R.S. (2020). Ametta Learning Model Design (Active, Fun And Without Pressure). Jurnal Tarbiyah, 27 (2), 113-129. DOI: 10.30829/tar.v27i2.773 
Iru, L., \& Arihi, L.O.S. (2012). Pendekatan, Metode, Strategi, dan Model-Model Pembelajaran. Yogyakarta: Multi Presindo.

Jumarniati \& Anas, A. (2019). Pengaruh Motivasi Belajar Dan Aktivitas Belajar Terhadap Hasil Belajar Mahasiswa Program Studi Pgsd. CJPE: Cokroaminoto Journal of Primary Education, 2(2). DOI: https://doi.org/10.30605/cjpe.222019.113.

Kariadi, D. \&Suprapto, W. (2018). Model pembelajaran active learning dengan strategi pengajuan pertanyaan untuk meningkatkan kualitas proses pembelajaran pkn. Jurnal Educatio, 12 (1), 10-21.

Kunandar. (2013). Penilaian Authentik (Penilaian Hasil Belajar Peserta Didik Berdasarkan Kurikulum 2013). Jakarta: Rajawali Pers.

Mulyasa, E,. (2007). Standar Kompetensi dan Sertifikasi Guru. Bandung: PT Rosdakarya.

Novianty, F,. (2017). Analisis aktivitas belajar melalui pembelajaran kooperatif tipe course review horay pada mata kuliah pendidikan kewarganegaraan. Sosial Horizon: Jurnal Pendidikan Sosial, 4(1), 11-2O.

Rusman. (2011). Model-Model Pembelajaran. Jakarta: Rajawali Pers.

Sanusi, U. (2013). Pembelajaran dengan Pendekatan humanistic (penelitian pada mts negeri model cigugur kuningan. Jurnal Pendidikan Agama Islam- Ta'lim, 11(2), 123-142.

Sardiman, A.M. (2016). Interaksi dan Motivasi Belajar Mengajar. Jakarta: PT Raja Grafindo.

Sari, L.W., Cawang, \& Rizmahardian A.K. (2017). Aktivitas Belajar Siswa Pada Materi Stuktur Atom Kelas X Mia Sekolah Menengah Atas Negeri 4 Pontianak. Ar-Razi, 5(1), 45-53. DOI: http://dx.doi.org/10.29406/arz.v5i1.652

Siahaan, F.B. (2014). Pengaruh model pembelajaran aktif tipe quiz team terhadap kemampuan pemecahan masalah matematika. Jurnal Suluh Pendidikan FKIP-UHN, 1 (1), 34-45.

Suprijono, A. (2009). Cooperative Learning: Teori dan Aplikasi PAIKEM. Yogyakarta: Pustaka Pelajar. 